\title{
THE ADVANCES OF THE BRAZILIAN JUDICIAL SYSTEM AND THE USE OF ARTIFICIAL INTELLIGENCE: OPPOSITE OR PARALLEL WAYS TOWARDS THE EFFECTIVENESS OF JUSTICE?
}

\section{OS AVANÇOS DO SISTEMA JUDICIÁRIO BRASILEIRO E O USO DE TECNOLOGIAS: CAMINHOS OPOSTOS OU PARALELOS RUMO À EFETIVAÇÃO DA JUSTIÇA?}

\section{VALTER MOURA DO CARMO}

Professor of the Law Graduate Program at the University of Marília (UNIMAR), where he has also completed a Postdoctoral Fellowship sponsored by the Brazilian National Postdoctoral Program/Coordination for the Improvement of Higher Education Personnel (PNPD/CAPES). He holds a Doctorate in Law from the Federal University of Santa Catarina State (UFSC), which includes research stays at the University of Zaragoza (Spain) with a scholarship from the Brazilian Sandwich Doctorate Program Abroad (PDSE/CAPES); and at the Federal University of Paraíba State (UFPB) with a scholarship from the Brazilian Academic Cooperative Project (PROCAD/CAPES). He also has a Master's degree in Constitutional Law from the University of Fortaleza (UNIFOR), including a research stay at the UFSC. He is the Director of Institutional Relations of the Brazilian National Council for Research and Post-Graduation in Law (CONPEDI) and Member of the Identification and Description Study Committee of the Brazilian National Standards Organization (ABNT).. ORCID: http://orcid.org/00000002-4871-0154. Email: vmcarmo86@gmail.com

\section{JEFFERSON PATRIK GERMINARI}

Master student in Law at the University of Marília (UNIMAR). Clerk of the Court of Justice of the State of São Paulo. ORCID: https://orcid.org/0000-0002-3741-5651. Email: jgerminari@tjsp.jus.br. 


\title{
FERNANDO GALINDO
}

Prof. Dr. Fernando Galindo, Catedrático de Filosofía del Derecho, Universidad de Zaragoza, España. ORCID: http://orcid.org/0000-0001-8339-1788. Email: cfa@unizar.es

\begin{abstract}
Objectives: To point out the technological advances registered in the Brazilian Judiciary System in the digital age, mainly the benefits that the engineering has provided in the improvement of artificial intelligence tools which reflect in the speed of judgments, as well as defining the limits of the use of such resources in view of the of the peculiarities of the judging activity in an immersive and sometimes exclusive demand, in the dynamics between texts and contexts.
\end{abstract}

Methodology: The methodology of this study is deductive coupled with techniques of bibliographical research by way of reviewing doctrine, journals, scientific articles and legislation. The study was strategically divided into a detailed investigation of themes that closely relate to the judicial system, the use of technologies and the effectiveness of Justice.

Results: Despite all technological advances, considering the specialties of linguistic resources, whether of an ontological or semantic nature, added to the peculiarity of the jurisdictional services and the completeness of social relations, it is concluded that such technologies, however developed they may be, they are not above the magistrates, but at their side as tools to support jurisdictional practice. The scientific intimate must definitely remain under the human domain, the only one capable of transforming the text by context into a legal norm capable of guaranteeing, at any time, the effectiveness of Justice in the midst of a society as dynamic and transformative as it is today.

Contributions: The discussion of working together between lawyers in the rational implementation of digital tools at their disposal and software engineers to simplify the legal world, through the development of intelligent systems, with the aim of understanding and applying their knowledge in the best way to solving questions about the administrative and technical complexity of the legal system, adequately responding to the demands of society.

KEYWORDS: Effectiveness; Technology; Justice; Language; Artificial Intelligence. 


\section{RESUMO}

Objetivos: Apontar os avanços tecnológicos registrados no Sistema Judiciário brasileiro na era digital, principalmente os benefícios que a engenharia proporcionou no aprimoramento das ferramentas de inteligência artificial que refletem na velocidade dos julgamentos, além de definir os limites do uso de tais recursos, tendo em vista as peculiaridades da atividade julgadora em uma demanda imersiva e às vezes exclusiva na dinâmica entre textos e contextos.

Metodologia: A metodologia deste estudo é dedutiva, associada a técnicas de pesquisa bibliográfica, por meio da revisão de doutrina, periódicos, artigos científicos e legislação. $\mathrm{O}$ estudo foi estrategicamente dividido em uma pesquisa detalhada de temas que se relacionam estreitamente com o sistema judicial, o uso de tecnologias e a eficácia da Justiça.

Resultados: Apesar de todos os avanços tecnológicos, considerando as especialidades dos recursos linguísticos, de natureza ontológica ou semântica, somadas à peculiaridade dos serviços jurisdicionais e à integridade das relações sociais, conclui-se que essas tecnologias, por mais desenvolvidas que sejam, não se posicionam acima dos magistrados, mas ao seu lado, como ferramentas para apoiar a prática jurisdicional. $O$ íntimo científico deve definitivamente permanecer sob o domínio humano, o único capaz de transformar o texto por contexto em norma jurídica capaz de garantir, a qualquer momento, a efetividade da Justiça no meio de uma sociedade tão dinâmica e transformadora como é hoje.

Contribuições: A discussão do trabalho em conjunto entre advogados na implementação racional das ferramentas digitais à sua disposição e os engenheiros de software para simplificar o mundo jurídico, através do desenvolvimento de sistemas inteligentes, com o objetivo de entender e aplicar da melhor forma os seus conhecimentos para a resolução de questões sobre a complexidade administrativa e técnica do sistema jurídico, respondendo adequadamente às demandas da sociedade.

PALAVRAS-CHAVE: Efetividade; Tecnologia; Justiça; Linguagem; Inteligência Artificial.

\section{INTRODUCTION}

The Judiciary Administration takes on new clothes at every moment in search of not only efficient but effective delivery of justice to the national courts. 
Historically, there is an increase in its structures, as well as an increase in the list of activities aimed at the protection of the fundamental constitutionally expressed safeguards, greatly reflecting the increase of the demands in recent decades.

Technological advances have undeniably also been welcomed (and are at all times) in the jurisdictional practice, resulting in very positive points regarding the speed of the procedural march and, consequently, in the outcome of the disputes brought to the judicial sphere.

In terms of efficiency, it goes back to the state ideology to optimize the performance of the work of the Judiciary, valuing the economy of public spending while the speed of achievements is prized, and the national judiciary is in the transverse direction to decrease the number of public servants, increase the claims and promote a higher productivity.

For this, the automation of justice and the use of technological resources are essential, without which it would be impossible to obtain the results achieved so far.

In a more advanced dimension, focused specifically on the reduction of lines of conclusions and judicial deliberations, the robotized systems operated by artificial intelligence arise, which are fruits of knowledge engineering, allowing the classification of deeds, petitions and providing guidance in the delivery of opinions, orders, decisions and sentences.

This is a challenge to judicial activity, since such appeals should be supporting actors and not major ones, replacing the scientific-juridical intimate that should prevail in each judge, a legal expert by express legal condition.

Through the deductive research method, the objective is to point out the technological advances registered in the Brazilian Judiciary System in the digital age, in particular, the benefits that knowledge engineering has provided in the improvement of artificial intelligence tools, reflecting in the speed of judgments, as well as defining the limits of the use of such resources, in view of the scientific reservations pointed out in the face of the peculiarities of the judging activity, in an immersive and sometimes exclusive demand, in the dynamics between texts and contexts. 
The work was strategically divided into a detailed study of points that closely relate the judicial system, the use of technologies and the effectiveness of justice; when they are considered together, they lead to the limitations of technologies in the current system. Chapter 2 is reserved for the historical background of the Brazilian judicial system, including the transformations that have taken place over the years, recognized as advances in their time and that, in one way or another, have gradually contributed to the current prospective ambience. Chapter 4 emphasizes the concepts of effectiveness and efficiency contextualized at the jurisdictional level in favor of ensuring justice, followed by the previously noted topic of advances in the judicial system, with a focus on digital processes and the evolution of operating systems. Item 6 is dedicated to the progress made with the reform of the Spanish justice administration system, in a thinking that is inclined to the communion of the positive experiences achieved there. Chapter 7 takes a critical approach to the limited use of knowledge engineering and the use of Artificial Intelligence technologies in justice operating systems to satisfy the claims made in the jurisdictional assessment. Item 8 addresses the human knowledge and particular ontologies of the judge in the protection of the effective consideration of the Judiciary. Topic 9 presents particularities of hermeneutic and semantic language in relation to new technologies, followed by the last part that describes empirical situations that arise as challenges to be observed, respected or overcome in the evolution of artificial systems in search of the effective guarantee of positivized rights.

\section{THE EVOLUTION OF THE BRAZILIAN JUDICIAL SYSTEM: RETROSPECTIVE VIEW FROM THE BRAZIL COLONY TO THE PRESENT DAY}

As a historical consequence, the Brazilian judicial system developed with the same characteristics of the Portuguese legal order. At the end of the Middle Ages, the structure of the Judiciary of Portugal was characterized by the administration of the king himself, whose jurisdictional function, in a pilgrim reign, was performed with the 
help of judges appointed by him, the so-called ombudsmen, and so they composed what was called the Court House of Justice.

Martins Filho (1999, p. 86) clarifies that in the face of Portugal's expansion by the reconquest of lands from the Iberian Peninsula to the Moors and the standardization of norms made possible by the 1480 Afonsine, 1520 Manoelinas and 1603 Filipina Ordinances, other figures emerged in the composition of this system, such as the judges of the land, also known as ordinary, non-literate judges, who were chosen by the people, and responsible for analyzing the causes related to the local law. There were also outside judges, and these were literate and appointed by the king to ensure the application of the royal commandments; of the corregidors, for the inspection of the work done by the judges in the villages where they passed and the desembargadors, who investigated the cases of appeal and supplication directly with the king, whose function was gradually changed so that they directly made the decisions on his behalf.

Martins Filho (1999, p. 87) explains that it was in the inaugural colonizing expedition, in the year of 1530 , that the first person with judicial powers, Martim Afonso de Sousa, stepped on Brazilian lands, and such powers were also entrusted to the other hereditary captaincy holders, but the primary landmark of the national judicial structure dates back to 1549, with the arrival of Desembargador Pero Borges and the establishment of the General Government, in the State of Bahia.

As the process of colonization was expanding in our country, the figures who previously only existed in Portugal were inserted here, as the people's judges, in 1644, also in the Bahian captaincy.

To prevent the abuse of power, the first collegiate body was created in 1587, and it was denominated the Court of Appeal; from this measure came the prelude of legal certainty to judicial decisions, since they would no longer be subordinated to the unilateral commandments of general governors and grantees. With the increase of the demands, other courts arose and thus the Brazilian judicial system was being structured. 
With the advent of the 1824 Constitution, a series of laws was published, such as No. 78 of March $31^{\text {st }}, 1824$, by Clemente Ferreira França, stating that all judgments should contain duly specified circumstances and reasons, imbued with foundation, precisely with the scope of extirpating judicial abuses. Although discretionary, there is concern about preserving impartiality and decision-making motivation in conformity with the precepts ensured by the Major Charter.

The Constitution of the Empire reserved the $7^{\text {th }}$ Title exclusively to deal with the organization of the Brazilian Judiciary, drawing its structure in three instances. The judges of peace and law were at the base, followed by the Courts of Appeal that were located in each province, and the Supreme Court of Justice located in the capital of the Empire, which analyzed the causes in which there were conflicts of jurisdiction between Relations, among others listed in its article $164^{4}$.

Although the figure of the Supreme Court was carved as early as 1824 , it was not created until 1828, with the enactment by Dom Pedro of the Law of September $18^{\text {th }}$, by detailing all its structure, including its composition by 17 literate ministers, chosen from the Court by seniority, awarded with the Council Title, including the choice of the president, to be entrusted by the emperor ${ }^{5}$.

An interesting characteristic of that time is that the attribution for the interpretation of the laws was entrusted to the Legislative Power, which in addition to making laws, accumulated the function of interpreting, suspending and even revoking them, pursuant to item VIII of article 15. Accordingly, the decisions of the Supreme

\footnotetext{
${ }^{4}$ This Court has the responsibility of: I. Granting or denying the Review of Causes, and in the way determined by the Law. II. Knowing the offenses and mistakes of the Office, which are made by its Ministers, the Relations, the Employees of the Diplomatic Body, and the Presidents of the Provinces. III. Knowing and deciding on jurisdiction conflicts, and the competence of the Provincial Relations.

${ }^{5}$ Art. 1 The Supreme Court of Justice will consist of seventeen literate Judges, drawn from Relations by their seniority, and to be awarded the Council title; they will wear a robe, and cape; they will be tre ated as Your Excellency, and the salary of 4:000\$000 without any other fees or benefit. And they will not be able to exercise any other job, except as a member of the Legislative Power, nor to accumulate any other salary. In the first organization, the Ministers who may be employed in this Court are those who will be abolished, without ceasing to continue in the exercise of these Courts, as long as they are not extinct. Conciliation could be brought before any Judge of Peace where the oath was found, even if it is not the Parish of his domicile.
} 
Court of Justice were not binding on the respective Courts, since no case-laws or judgments of general repercussion were created.

Such current practice was already provided for in Article $1^{6}$ of the Single Title of the Law of November 29 ${ }^{\text {th }}, 1832$, which promulgated the Code of Criminal Procedure and the provisional provision concerning the administration of Civil Justice, namely, the possibility of reconciliation of conflicts before the local judge of peace.

The Republican Charter of 1891 outlined a very characteristic scenario for the current system, by defining the figures of the federal and state courts in its article 55, as well as the Supreme Federal Court, which with the Amendment of September $3^{\text {rd }}$, 1926, by its attributions, assumed the function of standardizing jurisprudence, linking them to the other instances, which were nonexistent until then. The Superior and Regional Electoral Courts came into existence only with the advent of the 1932 Constitution.

Political regimes were crucial to the structural composition of Brazilian justice in the $20^{\text {th }}$ century, sometimes with the extinction of some areas, once restoring other instances, but the system of distinct degrees of jurisdiction has always been maintained.

In a more modern approach, the 1988 Federal Constitution brought the Superior Court of Justice to the discussion, so that binding jurisprudential understandings were present not only in matters of constitutionality control, but also for matters in the ordinary federal legislative order, being the head organ both for state and federal justice, resulting in the two current recursive systems, depending on the subject to be addressed.

In a closer look at the appeal dimensions, four levels can be highlighted, with the Supreme Federal Court (STF) on the top, followed by the Supreme Justice Court (STJ), the Regional Courts and the Courts of Justice of each state, and the first degree federal and state judges are below.

${ }^{6}$ Conciliation could be brought before any Judge of Peace where the defendant is found, even if it is not the Parish of their domicile. 
Thus, major advances are noted in the organic structure of the Brazilian judicial system for the delivery of consideration for specialized services, seeking greater efficiency of judicial demands.

\section{THE JUDICIARY AND THE JURISDICTIONAL FUNCTIONS}

The function of the Judiciary is to compose the existing conflicts of interest between the parties, regarding the analysis of the specific case, respect for the legislation in force and the fundamental precepts of man.

In relation to the modalities of dispute settlement in the private sphere, which is an unquestionable reality embodied in the arbitral chambers, the litigious solution is a private function of the State, being the source of the judge's power to provide the judicial protection entrusted to them, which by their acts determines the right and obligations of each party, resolving the controversies, at least as to the formal satisfaction, of the differences that were brought to their analysis.

Accordingly, for the desired declaration of the express will of the law, the judge must abide by fundamental procedural precepts when forthcoming final judgments ${ }^{7}$, such as impartiality of action, and should be placed as a third party who is equidistant from both parties, granting them equal treatment, giving them the right to produce evidence, which will serve as a foundation for the final decision.

As a maestro, he conducts the process by means of determined commands so that during its course there is no dissonance that influences the judgment and the full, harmonious foundation in the face of possible disagreements and the advocated right.

It is worth recalling article 93 of the 1988 Federal Constitution, which transfers the role of establishing the Statute of the Judiciary to the Complementary Law,

\footnotetext{
${ }^{7}$ It is worth highlighting that the sentences are classified in terminative and definitive, and the former put an end to the process, without analyzing the merit. The final sentences are those, which, focused on the specific cause, decide on the merits of the case by extinguishing the process, that is, blocking the right of the plaintiff to file a new action.
} 
observing the principles listed in the device, one of which is contained in item IX, with new wording given by Constitutional Amendment No. 45/2004, whose letter implies that all judgments of the Judiciary Organs must be substantiated, under penalty of nullity. Cogent icon in current judgments.

Thus, it can be seen that, following the development of the judiciary system, the figure of the judge also evolved in the Brazilian law, imbued with so many attributes to the guarantee of impartial pronouncements, detached from other powers and not biased, enabling the pure and full application of law in view of the fundamental guarantees protected by law.

\section{THE JUDICIARY AND THE SEARCH FOR THE EFFECTIVENESS OF JUSTICE}

What is the difference between being in an organized society and being in one where the law of the strongest and the state of savagery is impregnated is precisely the fact that in the former there is respect for fundamental rights and guarantees, which are institutes elevated to legal status, while in the latter there is no such concern.

Of course, in a complex world of relations, interests collide all the time, and for the maintenance of the Rule of Law, the institutions must be preserved and the Judiciary plays a fundamental role in maintaining the social order.

Rawls (2000, p. 6), in the opening lines of his book, regarding the role of Justice, recalls that "institutions are fair when no arbitrary distinctions are made between people in the assignment of basic rights and duties and when rules determine a proper balance between competing claims" in the game of social relations, without distinction of concessions and arbitrariness on the grounds of the person, but of the balance between rights and duties fundamentally prescribed by law.

In addition to the distributive function, Justice must be efficient in the judicial consideration, since delay can often be a preponderant factor in the expected social outcome; in this sense, Pinho and Côrtes (2014, p. 231) warn that "Effectiveness in 
court decisions is the minimum that current society aims for. There is no use in getting the right if you can't implement it."

Sadek (2004, p. 79) brings to the fore another face assumed by the Judiciary today, clarifying that the current constitutional political expression aims not only to "limit absolute power and ensure rights, but to be an instrument for the realization of social justice and the promotion of rights, by incorporating values of social, economic and cultural equality", thus absorbing other responsibilities beyond those initially entrusted.

Veronese (2007, p. 17) recalls the transformation that occurred in the judicial process, by the Political Charter, in the protection of the Democratic Rule of Law in political-social valuations, in the revisional judgments of the Executive, both politically and administratively. As a result, "the judge's role, as a passive and neutral element, has been steadily fading away. They are increasingly seen as an integral and inseparable part of the political process," contributing to the transfiguration of the suspicious image of the desired separated-impartial entity.

With the Constitutional Amendment 45, approved in 2004, the National Council of Justice (CNJ) emerged, a priori, in the organizational management plan, gradually becoming a major Organ for the strategic development of the Brazilian judicial work.

Since its implementation, numerous goals have been set, seeking greater efficiency of jurisdictional work. With the technological support used by the Courts, several goals are being met, so that in 2018 the report released by the CNJ pointed for the first time to stock growth of only $0.3 \%$, a break in the historical rise, which before had an average of $4 \%$ per year.

According to the statistics released by the $\mathrm{CNJ}$, compliance with the efficiency of jurisdictional provision in specific numerical data is observed; in fact, the name of the Council's annual report is Justice in Numbers 2018. But is it that efficient? In a cursory passage, it is possible to extract important information, such as the grand national judicial structure spread over 15,398 judicial units. Of these, nearly 11,000 correspond to state, labor and federal courts, more than 1,500 special courts and 2,700 electoral zones. 
It should be noted that the Court with the largest procedural record is the State of São Paulo, surpassing 20 million cases in progress. It is also the one with the largest number of magistrates and servants, although, proportionally, it is not the one with the largest number of actions per individual.

In spite of all the statistics presented, we tend to point to numbers that, although they may demonstrate movement and productivity, they do not provide conclusive data regarding the types of appeals filed, nor the numbers of decisions/sentences reformed by higher instance. Data of paramount importance for evaluating not only the production results materialized in numbers, but the effectiveness of satisfactory Justice that is delivered to those who seek the protection of their rights.

Obviously, indexes such as those raised here are indispensable to the assessment of the jurisdictional quality offered by the first and second degree, questioning the quality of the consideration and effectiveness in satisfying the intended protections.

Campos (2008, p. 8-9) reveals from a 2005 survey that more than half of the population does not trust the Judiciary, because they are urged by costly and bureaucratized access to Justice and lengthy judicial services that do not provide effective remediation for violations to safeguard.

According to an ICJBrasil report (2016, p. 15), between May and June 2016, 1,650 people, distributed in seven states and the Federal District, were interviewed about their trust in national institutions. The Judiciary held only the $7^{\text {th }}$ place, trusted only by $29 \%$ of the respondents, behind the Armed Forces (59\%), Catholic Church (57\%), Written Press - Newspapers (37\%), Public Prosecution Service (36\%), large companies (34\%) and TV stations (33\%).

Armelin (2006, p. 125) underscores the importance that should prevail in the effective consideration of full justice in the sense that "Effectiveness implies the presence of the justice trinomial, adequate results and speed of judicial protection rendered in order to obviate the negative impact to the Judiciary" in the provided 
service. Therefore, more than speedy, it is essential to have an effective and satisfactory judicial consideration.

\section{DIGITAL PROCESSES AND THE EVOLUTION OF THE BRAZILIAN OPERATING SYSTEMS}

In the very preamble of the 1988 Federal Constitution, justice is praised, among other precepts, as the supreme value of a fraternal society, whose pillars are based on social harmony, internal and international order and the peaceful settlement of disputes.

No wonder that in article 2 of the Federal Constitution, autonomy was established, as well as harmony among the powers of the Union, precisely so that the Judiciary could, independently of the actions of the Executive or Legislative branches, ensure the faithful fulfillment of the guarantees prescribed in the Major Charter, thus avoiding possible arbitrary actions that would alter the context of organized society, which was politically conquered through democracy.

Many assumptions were made available to the Judiciary for the effective exercise of its prerogatives as the principles established in items $X X X V, X X X V I I$ and LIII and that of the LV of the Article 5 of the Federal Constitution, namely the effective judicial protection, the natural judge and the due process of law.

However, it is unquestionable that there is a large number of lawsuits filed in recent decades, which led to the exacerbated accumulation of deeds, leading to intelligent measures by the Judicial Administration.

Ruschel and Rover (2009, p. 280) emphasize that in view of the development of Information Technology and knowledge management engineering in the improvement of e-government work (e-gov) "it is necessary to use a computerized tool that analyze a mass of data that allows the generation of indicators for process improvement." 
The late response to certain procedural classes may have distinct effects, sometimes very worrying to social anxieties. In the field of criminal law, lengthy sentences reflect on the sense of impunity and for the species deriving from the patrimonial rights of Civil Law, significantly influencing the economic power of the parties, since while they are stagnant, the pending processes prevent them from being able to take measures of individual economic growth with what they want to see satisfied in the sentence.

For Sewald Junior (2012, p. 49) "the time of the process is crucial for the fulfillment of the jurisdictional role of the Judiciary" precisely to guarantee the Rule of Law, once it is the means by which the end is reached and, therefore, the more skillful the mechanisms of operationalization are, the more efficient the judiciary service will be.

Rover (2000, p. 208) further points out that today "more than in any other time in the legal history of mankind, there is a need to address both the administrative and technical complexity of the legal system, adequately responding to the demands of society", in a joint work between lawyers in the rational implementation of the digital tools at their disposal and software engineers to simplify the legal world through the development of intelligent systems.

The first decade of the $21^{\text {st }}$ century was marked by very positive measures aimed at solving such impasses, following an efficient operationalization of Justice.

The first change was the reform of the Judiciary provided by Constitutional Amendment No. 45/2004, when the National Council of Justice was created, with the function of external control of the Judiciary in strategic management plans to make judicial activity more efficient, also cumulating the correctional function.

Another important measure was the advent of Law no. 11.419, of December 2006, which amended part of the Code of Civil Procedure regarding the computerization of judicial proceedings, and was considered a great advance to the speed in the processing of the deeds, enabling the communication of acts and the transmission of the piece digitally and practically instantly. 
This led to the opening of a universe of possibilities as new technologies were emerging in the market. Perhaps a serious mistake to be remedied is the one advocated in article 8 of the aforementioned law, which enables each Judiciary Body to develop their own systems, thus providing the use of different software with different applicability by different Courts.

The greatest advantage obtained with digital processes is their dynamism, since it allows the parties to have broad and direct access to the deeds, and they can petition at any time, regardless of the working lines in which the processes are located, without harming their very ritualistic course and allowing any claim to be led to the masterful conclusion and consequent deliberation, a situation which in physical processes would be impossible to occur immediately.

In 2013, the National Council of Justice issued Resolution No. 185, establishing the Electronic Judicial Process (PJe) as a system for processing information and practicing procedural acts, establishing so many parameters for the adequacy of the deeds in digital media, and the States may effect digital feats through other operating systems.

According to information released by the National Council of Justice (2018, p. 90-91), a data from 2017, besides the PJe there are eight other electronic systems in use in courts and related units (Themis, Tucujuris, SAJ, E-proc, SCPV, UDI, EJUD, PROJUD); nine courts use the PJe system (TJBA, TJCE, TJDF, TJMT, TJMG, TJPA, TJPE, TJRN and TJRS). It is noteworthy that five courts reached the rate of $100 \%$ of cases in purely digital proceedings (TJAL, TJAM, TJMS, TJTO and TRT9).

Aiming at fully complying with administrative efficiency, the CNJ launched Resolution No. 194 of May 26 th 2014 establishing the National Policy of Priority Attention to the First Degree of Jurisdiction, implementing plans and productivity targets to be reached by the Courts for rational equalization of the judicial work in progress in the country.

It was found that the largest number of new processes is in the First Degree, and consequently workload and productivity by both magistrates and servers, whose 
performance, since 2013, is steadily rising, reaching the point that in some States they tripled their tasks when compared to the Second Degree Courts (CNJ, 2018, p. 102).

According to the report (CNJ, 2018, p. 145), in recent years there has been a decrease in the average duration of the proceedings with the increase in the number of sentences issued and, consequently, of concluded sentences, which indicates the positivity of the implementation of electronic systems and the works headed by the CNJ.

A problem to be overcome by the national Judiciary is that there is more than one automated system in operation. Despite the respect for the respective administrative autonomies, in a trivial view, it could be concluded that the coexistence with different systems would not influence the progress of the deeds.

However, we cannot forget to mention the usual cooperative work carried out among the Courts, either in the fulfillment of Rogatory Letters of Order, or in the continuation of the deeds by redistribution and even the appeal remittances to higher courts.

With the implementation of a unified system, redistributions and compliments will enable faster action, given that they will surpass still existing phases, such as protocol services provided by lawyers and those practiced by judicial distributors.

In Brazil, there is a Judiciary Power with a heterogeneous and precarious electronic system, as each Court uses different digital platforms for procedural operationalization, many of them still with a significant number of physical processes in progress; this is a quite opposite reality when compared to the availability of artificial intelligence resources available to the Justice service, explained precisely in the face of the great competition among the service providers, which make available, at any moment, attractive new automated tools to facilitate the conduct of judicial and administrative acts, thus meeting local legal demands. 


\section{EXPERIENCE OF THE JUSTICE ADMINISTRATION REFORM IN SPAIN}

In Spain, Organic Law No. 19 of December 23 ${ }^{\text {rd }}, 2013$ promoted the reform of the Judiciary, bringing in the first lines of the reason statement, as its main objective, the transformation of a system aimed at a fast acting, effective, and quality Justice, endowed with modern methods and uncomplicated mechanisms to fulfill a satisfactory service in a reasonable time, while safeguarding the necessary legal certainty for the litigants.

An effort promoted by the Ministry of Justice committed to the modernization of the Judiciary System with the collaboration of the General Council of the Judiciary, the Attorney General's Office and other public administrations with related powers. The Spanish Judiciary System has the Judicial Office in its structure as an instrument to support the judicial activity of judges and courts. Such model aims to break the classic configuration, aiming to generate greater efficiency, rational use of human and material resources, in the improvement of the provision of the desired public service.

The Judicial Office is basically divided into two work fronts. The first one is the Direct Support Procedure Units to assist judges in the performance of their duties, and the second one is the Common Procedural Services, under the direction of a Justice Administration lawyer, taking on tasks involving management and support in actions derived from the application of procedural law. There are also Administrative Units of human and material resources management to better meet existing demands.

The advantages derived from the Spanish model can be synthetically defined by the orientation and careful division of the activities performed in the Judiciary Administration, in particular the services of jurisdiction, notary procedure and administrative ones. All this dynamics is under the supervision of the Inspection System, whose main objective is to evaluate the operation, the effectiveness and the quality of the notary activity, by analyzing and controlling its performance and proposing recommendations for organization and improvement in the efficiency of the performed work. 
In retrospect of the Spanish reality, it is possible to mention the existence of some specific and significant problems. Iglesias and Arias (2007, p. 139-141) report that the Spanish system presented important problems of effectiveness and efficiency, and that there were pending issues and the delay in settling the disputes among the functional problems of the judicial organs, besides the lack of quality of the judicial consideration and deficiency in the execution of the judgments.

Bringing to the current context, Carvalho (2017, p. 117) mentions that there are several complaints regarding the Spanish judicial service. According to the latest balance released in 2015 , from the 12,658 records of complaints, $68 \%$ were related to the operation of judgments and courts; $15 \%$ disagreed with the outcome of the decisions. Other complaints were related to the lack of understanding of the terms and languages used in the sermons, the lack of attention to respect and attendance to the courts, the long waiting time and the unpunctuality in holding the hearings. It also adds the lack of agile and technologically advanced consideration, weak in the use of new technologies.

Aiming to alleviate these problems, the Spanish Ministry of Justice presented an e-Justice Government plan for 2015 and 2016, aiming at the implantation of a modern, integrated system with functional autonomy in the Judiciary, being divided into four stages. The first one corresponds to the improvement of the system and communication infrastructure, which had been much debated so far; the second stage refers to the modernization of end-user computing; the third one is the implementation of new functionalities such as LexNet for procedural consultation and digital signature; and a final step is evolution of the Fortuny management system, including the management of procedural matters, registration of specialized matters, procedural follow-up, control of the duration of legal proceedings, among others. Currently there are several procedural management systems being implemented in Spain. Others, developed in different autonomous communities, are: Adriano, Avantius, JustiziaBAT, e-justícia.cat.

In a comparison between the Brazilian and Spanish systems, it is possible to identify that the former is organized in the form of specialized justice, divided by specific 
areas, while the latter opts for the prevalence of unified, integrated justice. Notwithstanding the great Spanish judicial reform, it is possible to conclude that the artificial intelligence techniques used in the country are scarce; in Brazil, although permeated by an inhomogeneous organizational structure, it benefits too much from the resources developed by knowledge engineering, contributing to better service delivery.

\section{KNOWLEDGE ENGINEERING IN THE JUDICIAL SCOPE: ALLIED OR OBSTRUCTIVE TO THE EFFECTIVENESS OF JUSTICE?}

Rota et al. (2016, p. 414) points out that "the use of specialized computerized systems can result in speed and productivity, especially in performing more routine and repetitive tasks, by eliminating the so-called dead time in the process", specifically those pending of notary impulse.

Instigated by the constitutional premise of the efficiency of public services, the use of available technologies has become a great ally in the management of court provision, as there is a tendency to see a greater number of demands brought to the scrutiny of the Judiciary. Against this, there is a decrease in the proportion of servers to manage deeds.

Thus, numerous managerial improvement measures have been taken by the Courts in order to mitigate the impacts of this growing upside down situation, aiming at better management of resources with personnel as it intends to optimize the work performed by the judicial offices.

Knowledge engineering (EC) has had a strong impact on building systems based on systematic and controlled knowledge in justice courts across the country.

Sewald Junior (2012, p. 71) explains that knowledge engineering is responsible for "acquiring expert knowledge (collection, selection, decomposition, composition, and modeling) and existing knowledge in databases, systems, or scope- 
related documents from this expert", thus being an interesting resource for the elaboration of decisions, contributing to the desired procedural speed.

Its basis is rooted in Artificial Intelligence (Al) and differs from it precisely in improving contextual applications of information by creating intelligent systems for human assistance; what used to be restricted only to the transfer of information passes to the scale of cognitive modeling.

Sewald Junior (2012, p. 72) also highlights countless intelligent tasks that can be made available such as "predictions, pattern recognition, classification, diagnosis, ability to learn from new facts, making inferences, making analyzes, making decisions" , warning, even if for the expected effect to occur, the knowledge engineer must stick to the various agents involved in the production of knowledge, as well as their respective users, including by identifying opportunities and cognitive demands to adjust possible bottlenecks with intelligent tools.

The peculiarity of intelligent information management in the judicial context is that together with the knowledge produced there is the magistrate's individual and subjective foundation for the specific case, making it an interesting challenge for engineering to soften such particularities, providing the judge with more advanced technologies that, if not a substitute, provide them with aid mechanisms never seen before.

Sewald Junior (2012, p. 59) further asserts that "The reasoning of the sentence is important for the parties and society itself in order to know that the Judiciary is thinking about the matter, about the claims", so the real case cannot be restricted to being abstract-generic, since the cases that require filigree legal interpretation by the judge are not rare.

In search of an artificial knowledge system that took into consideration both technical and human aspects in view of the insufficiency of the mechanistic and descriptive method to the development of the legal science, also subjective, the CESM model was created by the Argentine philosopher Bunge, providing a clear vision through connection between internal components in the search for understanding knowledge systems (SEWALD JUNIOR, 2012, p. 76-77). 
Methodologies were also developed for the production of artificial knowledge, such as Commonkads, explained by Sewald Junior (2012, p. 77) as a "methodology that provides conceptual representation and the construction of a structured modeling of knowledge inherent in a scenario where specially agents are identified, and the tasks performed by them", including those intensive to the knowledge inserted in an organizational context to support the knowledge management; the complete substitution of cognitive production is not intended, and it is a support mechanism for management.

The contextuality of this system encompasses the rise of organizational context, considering its characteristics, tasks and performed activities, as well as the involved agents.

The ontology originally used for the study of what already exists assumes a new aspect when enjoyed in artificial intelligence standards. Batres et al. (2005, p. 76) clarifies that such a tool assumes the peculiar characteristic in general terms "to denote conceptual systems used as vehicles that promote the sharing and reuse of knowledge", a mechanism of intelligent integration of information retrieval and extraction in cognitive management.

Such devices enable the provision of common sense through sharing within the same domain of information produced among its agents, expanding the possibilities of terminological relations and corresponding aspects related to broader orientation, synonyms and counterparts and associations in general.

Although technologies are available to the Justice Administration to assist in procedural management, their exclusive use is foolhardy, since, however refined such resources may be, blindly entrusting them with the peculiarities of each particular case would disfigure the legal certainty incumbent on the protection of the State, practiced by the magistrate, who has been given jurisdiction to settle disputes, in the individuality brought to their particular appreciation, even allowing certain claims to go unnoticed by due court deliberation.

Flores (2019, p. 89) points out that "The presentation of facts in an initial petition, in a contestation or even in each interpretation involves observations that 
mean a certain construction of reality, elaborated from the perspective of the system of law", thus, there are so many peculiarities that they must be analyzed in their individuality and details, in judging valuation.

\section{HUMAN KNOWLEDGE AND ONTOLOGICAL PARTICULARITIES}

The birth of Greek philosophy was marked by the pre-Socratic figure concerned with the search for explanations on what the Being is, whose expression is translated by the Greek word ta onta (existing things, beings), restricted to the study of the origin, of the order of the world, that is, in ontology by the search for understanding about things.

Chauí (2002, p. 110) warns that since this period there have been disagreements about the human capacity for knowledge, exemplifying the fact that it is affirmed that "reality (Being, Nature) is rational and we can know it because we are also rational; our reason is part of the rationality of the world, participating in it."

The thoughts of Heraclitus, Parmenides and Democritus stand out. The first one concludes that reality is the harmonious state of setbacks in a world in constant transformation, drawing differential lines that humans can draw between the perceptive thinking of the static world and the knowledge attainable by thought amid continual world changes.

In contrast to Heraclitus, Parmenides states that one can only know what remains unchanged in the midst of the ever-changing world. He admits the constant transformation, but clarifies that "we perceive unthinkable changes and we must think immutable identities" (CHAUÍ, 2002, p. 111).

Democritus, through the theory of atomism, points out that, like atoms ${ }^{8}$, there is a distinction that must be well demarcated about what is known through different perceptions than what is assimilated through human thought, which makes it possible to know the essential substance of indivisible atomic perception.

${ }^{8}$ The smallest indivisible particle of all things that can take different forms depending on its arrangement. 
Although characterized by positions differing in some respects, Greek philosophers already showed some concern with the pursuit of true knowledge. Chauí (2002, p. 111) concludes that "From the beginning, philosophers have realized that our thinking seems to follow certain laws or rules to know things and that there is a difference between perceiving and thinking."

The Sophists concluded that it is impossible to know the Being and that one can only obtain subjectivist opinions about reality, and man must use the linguistic tool for human persuasion about his own ideas. The truth is placed in a plane of opinion and persuasion, and the language is an instrument that puts itself even before the perception and the thought.

Several theories about knowledge and truth can be found through the study of philosophy, each with its own peculiarities, and the possible extensions between truth, rationality, perception, consciousness and knowledge are not a consensus among them; what is denoted is the search for such relationships among people in the interaction with the environment and the constantly occurring changes, something that seems to be far from artificial intelligence, the prevalence of intelligible imaginary creation.

Bringing these concepts to the brim of artificial intelligence resources, one should consider to what extent such tools can be truly allied to the judge as labor aids or improperly replace their conscience in the human rationale and reasoning of decisions consistent with the object of outrage and that were brought to the sieve of the contentious jurisdiction for private analysis and deliberation of the just.

Carvalho (2018, p. 3-4) emphasizes the importance of immersing into scientific knowledge during the construction of knowledge, surpassing the uncritical limits of affirmative propositions about positive law. The aim, in the current context, is to advance into broader paradigms that enable greater interaction in a system of incessant feedback on the scientific work of human thought, that is, "the philosophical breath, in the superior form of critical meditation, must be present throughout the extent of the work". 
The wide range of referential systems available to the interpreter for the examination of the object of study must be added, including the contact between the cognoscente and the object of knowledge, amid the prescriptive discourse of positive law, social reality and their particular experiences, all are preponderant factors for the construction of the legal discourse, including the deepest and impartial feeling lodged in each jurisdictional interpreter.

\section{THE PECULIARITY OF LEGAL HERMENEUTICS AND SEMANTIC LANGUAGE}

A great paradigm to be faced refers to the legal hermeneutics that deals with the interpretation of the norms for the understanding and application of the law, the game of current law and materialized norm in the jurisdictional decisions.

The constitutionalization process of some tutelages and the ways directed to safeguarding the Democratic Rule of Law in the promotion of social welfare were preponderant to the influence of the Institutions in the application of the prescribed rule to cases brought to judicial review; in the words of Streck (1999, p. 31-32), it contributed to a certain dysfunctionality of Law, adding that "there has not yet been, in the hermeneutic plan, a proper filtering - in view of the emergence of a new production mode for law represented by the Democratic State of Law - of this (old/outdated) Law".

Another obstacle to be faced refers to the theoretical common sense as the basic knowledge of the legal and epistemological scientific discourse. In the words of Streck (1999, p. 52), "it stifles interpretive possibilities. When subjected to the pressure of the new, it (re)acts by institutionalizing criticism", delimiting the hermeneutic process on positivist rational bases.

Faced with the crisis experienced by the institutions, either structural with the lack of servants for the rapid judgment of the processes; or functional, in jurisdictional dealing with outdated (or even nonexistent) laws for the protection of rights as was the recent case of framing homotransphobia as a crime of racism ${ }^{9}$; all jurisdictional activity

${ }^{9}$ See ADO 26. 
is put on the alert in the face of the need to fully meet the demands and the effective realization of justice.

Streck (1999, p. 67) makes a sharp critique on the difficulty faced by legal dogmatism in dealing with social phenomena, in a tendency towards a specialized, closed and formal system, clarifying that a legal cultural system based on standard production of petitions and judgments was implemented in the country, and the introduction (still today) of jurisprudential amendments out of the context of concrete cases in the decision-making texts are not rare.

Such measures, in the majority of cases, end up putting aside the main actors, which are the parties themselves, with the peculiar situations that were brought to the discussion, by making use of the decision-making mechanics of exhaust valves for the drying up of work queues in favor of the results to be released by the CNJ of the judicial productions. An apposition of meanings between judicial efficiency and effectiveness of justice.

The interpretation of law is of fundamental importance so that the intended protection is actually achieved by the Courts, since, most of the time, the exegete needs to conglomerate various conceptions to fit the legal predictions into the social fact brought to their analysis, and here it is important to emphasize the need for the prevalence of the magistrate values of the law, not the framed values of the magistrates in the formal outcome of cases. Indeed, Streck (1999, p. 73) reinforces that "The interpretative/hermeneutic process has (should have) a productive character, not merely reproductive", hence the importance of legal scientific production.

The process of legal interpretation takes into account several phases, Ferraz Jr. (1980, p. 76) clarifies that "the literal, grammatical or logical-grammatical method is only the beginning of the interpretative process, which must start from the text. Its purpose is to make the letter compatible with the spirit of the law", here is an adaptation of linguistic expressions between language and thought.

However, literality is only the initial surface to be explored by the interpreter who has a duty to immerse themselves in the peculiarities of each case in order to return to the jurisdiction the true expression of justice in contextualized decisions for 
the specific case. Being eminently objectivist in the face of the past judgments of the Superior Courts would preclude any possibility of guaranteeing new protections arising in different guises, which are, in addition, routinely presented to the judges. It must not be forgotten that Law is an autonomous entity in constant transformation.

The currents of objective and subjective interpretation of judgments come from this. The subjectivist current allows interpretation of the norm in the recognition of the legislator's will, instrumentalized by the genetic, historical aspect of the application of the norm, while the second one delimits the interpretation by the will of the law, restricting itself to the structural aspects of the norm and the sociological capture techniques.

Cases being judged on a subjective aspect and objective basis are not uncommon, coexisting in Brazilian law, if not peacefully, in a relationship of respect for the fundamental social protections brought to the most diverse sieves in all judicial instances.

Another important factor is the semantic field; Bechara (2015, p. 413) asserts as to semantic changes in the lexicon, with diachronic structural semantics being the study of changes in such functionalities. Pagliaro (1952, p. 210) still warns that "words are a kind of shell, which we have to touch our ears with humble attention if we are to learn the voice within them."

Thus, although knowledge engineering can contribute significantly to jurisdictional work, it should be taken with reservations so that it does not mechanize the effectiveness of Justice also through its reasoning, since just as words can take on different meanings depending on the employed context, each presented situation, however similar in nature it may seem, is at first endowed with incalculable particularities, only assimilated by the magistrate when they bend over it in deep assault.

The interpretation of legal science assumes a very peculiar position when compared to other sciences, requiring from the interpreter countless potentialities for the outcome of the fair and the effective. Carvalho (2018, p. 188) teaches that motivated by the difficulties of interpretation in view of the peculiarities that confront 
him with the law "the exegete finds themselves in the contingency of casting a retrospective look, recovering the space of the fundamental notions, where the basic concepts of their Science are deposited", immersing themselves in juridical reflection, sometimes "a philosopher of their knowledge" (CARVALHO, 2018, p. 188) to support the thesis in dogmatic field.

Language plays an important role in interpreting functions, because in addition to reporting to legally prescribed data, it is also through it that the legal norm is formed.

Carvalho $(2018$, p. 188) points out that it is unquestionable that the legal phenomenon is manifested through written and unwritten prescriptions, but "it is also certain that we cannot consider the manifestation of law without language, either idiomatic or not, which can serve as a vehicle of expression", in a kind of attribution of values, including cultural ones brought by language, part of the social inferences of which it is part, in the midst of its axiological contents.

The use of artificial resources should be viewed with caution, because in the face of wordplay, the primary construction for the representation of human consciousness is allowed, but the decisions must be properly contextualized to the specific case. Carvalho (2018, p. 198) even points out that "there is no text without context, because understanding the message necessarily presupposes a series of associations that we could refer to as linguistic and extralinguistic."

In this sense, besides the context of immediate language to the text intertwined with formal associations, there will be undoubtedly the historical-social sense in which the ideological formations of each exegete are impregnated, in an intimate relation of the structural internal relations and those externalized by the historical and sociological production circumstances.

A challenge to knowledge engineering goes along the line of facing the three dimensions of semiotic analysis in the interpretative process, namely, the syntactic, semantic and pragmatic function; this invariably keeps the jurist as protagonist of the judicial function, since the law is constantly changing and the legal scientist must always be alert to any social change in the sensible perception and abstraction of the norm. If this were not the case, there would be no importance to scientific literature on 
the fundamental basis of consideration of robust judgments observed in important Supreme Court judgments in breaking paradigms. The offer of jurisdictional consideration involves major concepts in deep approach of so many institutes already defined here in favor of the prevalence of fundamentally described values.

\section{EMPIRICAL CHALLENGES TO BE OVERCOME}

Judicial practice has faced countless situations that make it impossible to sustain automated decision-making, dissociated from the peculiar valuation of each judge, whose noncompliance gives way to intolerable violations of fundamental rights.

In family actions, such a situation becomes more acute, and the judge's attentive eye to the sensitivity of the particular case must supply the inert positivization of the legal text and artificial intelligence systems, taking into account complex factors linked to the individual needs of the litigants that go beyond any objectivist common sense ritualistic.

Food claims cover various dimensions of the law, as well as the most distinct social classes, becoming one of the most effective forms of the primacy of solidarity, a very widespread principle in today's civil environment. In cases of marital dissolution, compensatory foods are born, in the words of Madaleno (2008, p. 725), they refer to the burden that arises in the face of the economic imbalance that may affect the most dependent individual, forcing the opposing party to the material consideration, according to the lifestyle and personal livelihood they previously shared.

Such predictions also find a landing in Article 270 of the French Civil Code, which highlights the possibility of compensatory binding in the face of marital breakdown that creates an imbalance of conditions previously shared by the spouses. To this end, it proceeds with the provisions of Article 271, asserting the considerations that must be taken by the judge in setting the compensation amount, taking into account the duration of the marriage, the age and health conditions of each individual, their qualification and professional status, among other factors that limit the use of cold 
robotic analysis filters. In the same sense, Spanish Civil Law presents Article 97 and Italian Civil Law Article 5 of the Law of December $1^{\text {st }}, 1970$.

The amounts to be arbitrated as child support deserve special attention, given that, considering the provision contained in paragraph 1 of article 1.694 of the Brazilian Civil Code, which provides that the setting of the quantum will be proportional to the needs of the complainant, only in a particular and very subjective analysis of the judge, based on factors that overcome the shortcomings of legal hermeneutics, the fair and effective consideration for each case can be defined, as the needs and standards of living vary between family groups.

Thus, it is possible to affirm that the weighted analysis of the economic and social condition experienced by the family before dissolution is beyond the possibilities of artificial intelligence, as well as any financial difficulties that they may face during the process, the number of children possibly obtained outside marriage and their respective needs regarding food, educational and health expenses, number of dependents and food dependents, under which conditions each one is, factors that deserve to be carefully considered in the personalized and exclusive decision of each judge.

These are factors that sometimes justify the fixing of provisional maintenance, such as those discussed in the request of Provisional Guardianship No. $834^{10}$, ruled by the Brazilian Superior Court of Justice, which analyzed the granting of the suspensive effect of the fixing of arbitrated maintenance in the order of $R \$ 81,000.00$, quite distinct from that commonly observed in the massive procedural of one third of the national minimum wage, until further investigation of the real financial conditions encountered by each feeder.

Civil liability for environmental damage is another very interesting front when analyzing the unfeasibility of the use of exclusive artificial intelligence systems in the assessment of claims, since the burden to be applied to the violator has for its primary scope not the mere use of compensatory measures to the detected degradation, but also to restrain the reiteration of this kind of practices, in a joint study of the corporate

${ }^{10}$ See STJ - TP: 834 SP 2017/0204641-5. 
resources to be dispensed with and investments, absorbed profits and indemnity risks. Maluf (2009, p. 9-10) clarifies that civil liability in environmental matters gives rise to the idea of rescuing the harmony and balance of harmful action, but also the intention to discourage new attitudes from recurring.

Thus, the judge's analysis in setting compensation should take into consideration a thorough study of the extent of damages and risks, but also consider the economic capacity of each entity, preventing corporate profits from overriding environmental preservation interests, discouraging solidarity liability that should promote the guidelines of all companies, so that the value to be reimbursed by a micro company that deliberately disposes of waste in tributaries streams is not the same to be applied to a multinational that occasionally does the same, whose impact, if the value was the same, would not have the same effects.

Covering the artificial functionality in the field of Criminal Law is essential to mention the figure of the judge in the consideration of the dosimetry of the penalty according to article 59 of the Penal Code, since its purpose is to reprove and prevent the criminal act, taking into consideration intimate factors, sometimes only perceptible to the judge's watchful eyes, such as the defendant's culpability, the social conduct practiced, their personality, motivation of the crime, background, circumstances and consequences of the committed act, the victim's behavior, which sometimes is not transmissible to formal internal processual records.

Another challenge to hermeneutics on the substantiation of robotic artificial intelligence resources is related to the verification of non-literal documents and evidence, such as the presentation of audiovisual resources deposited in the notary's office, photographs and media of the hearing, evidence available to support the allegations of the parties, which lead the judge to their free conviction in sentencing or even in the deliberation the solves proceedings at the time of granting evidence to be produced by the litigants. The peculiarity of each case must be taken into consideration for the optimization of the procedural rite, and must be consistent with the right to protect, so that there is a right, effective and prompt consideration of the Justice. 


\section{CONCLUSION}

In light of the foregoing, it is noted that the Brazilian Justice has undergone significant changes throughout its history, both in order to improve its organic structure and to offer a specialized and efficient judicial consideration.

The political bias assumed in overseeing the legality of the acts practiced by the Powers, in addition to the rigorous disputes, which are reflections of the liberal Constitutional State with a view to social welfare, has contributed to the increase of jurisdictional tasks, in increasing demand in recent decades.

The use of technological resources promoted by knowledge engineering and the digital process system are strong allies to the procedural speed, very important for the offer of effective Justice and the economy of public resources, a favorable and indissoluble voice when faced with the higher premises of administrative efficiency.

Despite all the advances, due to the inherent peculiarity of linguistic resources, whether of an ontological or semantic nature, added to the unique peculiarity of the jurisdictional services and the completeness of social relations, it is concluded that such technologies, however developed they may be, cannot stand in front of the magistrates, but at their side, as tools to support jurisdictional practice.

From the jurisdictional empirical practice, it is possible to realize that certain actions require sensitive analysis with distinct applications, depending on the specific case, disarticulated from deliberately prepared standards, motivational circumstances closely linked to the judge's motor and subjective perceptions, as in the case of family actions, dimensioning and determination of environmental damages, civil indemnity, the dosimetry of penalties and the analysis of non-literal procedural pieces and audiovisual resources, sometimes not included in the judicial acts themselves, resources available in media deposited in notary offices available to the judge and the parties and that will certainly serve as a basis for judicial reasoning.

The scientific intimate should definitely remain under the human domain; the only one capable of transforming the text, by context, into a legal norm capable of 
guaranteeing, at any time, the effectiveness of Justice in the midst of a society as dynamic and transformative as it is today.

It is concluded, in a comparison between the Brazilian and the Spanish Judicial Administration, that while the former, despite great advances in the improvement and use of artificial intelligence, still needs a structural reform, just like the Spanish one, with the use of a unique and integrated electronic system. On the other hand, the Spanish Justice, by having already overcome this stage, could use the resources used in the Brazilian judicial electronic government to provide more efficiency of the service rendered to the population and consequent satisfaction to the jurisdictional ones.

\section{REFERENCES}

BATRES, E. J. Q.; OLIVEIRA, A. de P.; GABRIELLI, B. V.; AMORIM, V. P.; MOREIRA, A. Uso de ontologias para a extração de informações em atos jurídicos em uma Instituição Pública. Encontros Bibli, Florianópolis, n. 19, 1ํ sem. 2005.

BECHARA, E. Moderna gramática portuguesa. 38. ed. Rio de Janeiro: Nova Fronteira, 2015.

BRASIL. [Constituição de 1988]. Constituição [da] República Federativa do Brasil. Brasília: Senado Federal, 1988.

. [Constituição do Império de 1824]. Constituição Política do Império do Brazil (de 25 de março de 1824). Rio de Janeiro: Secretaria de Estado dos Negócios do Império do Brazil, 1891. Disponível em: http://www.planalto.gov.br/ccivil_03/constituicao/constituicao24.htm. Acesso em: 9 jul. 2019.

Assembléia Geral. Lei de 18 de setembro de 1828.Crêa o Supremo

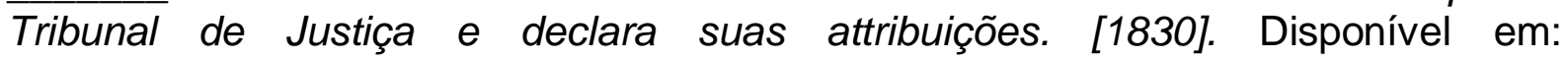
https://www2.camara.leg.br/legin/fed/lei_sn/1824-1899/lei-38214-18-setembro-1828566202-publicacaooriginal-89822-pl.html. Acesso em: 9 jul. 2019.

. Lei de 29 de setembro de 1832. Promulga o Código de Processo Criminal de primeira instancia com disposição provisória ácerca da administração da Justiça Civil. 1834. Disponível em: http://www.planalto.gov.br/ccivil_03/leis/lim/LIM29-11-1832.htm. Acesso em: 9 jul. 2019. 
. Conselho Nacional de Justiça. Resolução no 194/2014, de 26 de maio de 2019. Institui Política Nacional de Atenção Prioritária ao Primeiro Grau de Jurisdição e dá outras providências. Disponível em: http://www.cnj.jus.br/images/resol_gp_194_2014.pdf. Acesso em: 19 ago. 2019.

. JUSTIÇA em Números 2018. Brasília, 2018. Disponível em: https://www.cnj.jus.br/files/conteudo/arquivo/2018/08/44b7368ec6f888b383f6c3de40 c32167.pdf. Acesso em: 9 jul. 2019.

Decisão do Governo N. 78, de 31 de março de 1824. Determina que os juízes fundamentem as sentenças que proferirem. Palácio do Rio de Janeiro, 1824. Disponível em: https://www.camara.leg.br/Internet/InfDoc/conteudo/colecoes/Legislacao/LegimpG_53.pdf. Acesso em: 9 jul. 2019.

CAMPOS, A. G. Sistema de justiça no Brasil: problemas de equidade e efetividade. Brasília, 2008. Disponível em: http://repositorio.ipea.gov.br/bitstream/11058/1472/1/TD_1328.pdf. Acesso em: 09 jul. 2019.

CARVALHO, P. de B. Direito Tributário: Linguagem e Método. 7. ed. São Paulo: Noeses, 2018.

CARVALHO, A. D. Z. de. Como se guardam os guardas? Limites institucionais à independência judicial no Brasil e na Espanha. Revista Brasileira de Sociologia do Direito, v. 4, n. 2, p. 98-125, mai./ago. 2017.

CHAUÍ, M. Convite à filosofia. 12. ed. São Paulo: Ática, 2002.

ESTADOS UNIDOS DA AMÉRICA. [Constituição da República de 1891]. Constituição da República dos Estados Unidos do Brasil (de 24 de fevereiro de 1891). Rio de Janeiro: Congresso Nacional. Disponível em: http://www.planalto.gov.br/ccivil_03/constituicao/constituicao91.htm. Acesso em: 9 jul. 2019.

FERRAZ JÚNIOR, T. S. A ciência do Direito. São Paulo, Atlas, 1980.

FLORES, G. G. F. Direitos Humanos, novas tecnologias e resiliência do direito. Revista Argumentum, Marília, v. 20, n. 1, p. 73-96, jan./abr. 2019. Disponível em: http://ojs.unimar.br/index.php/revistaargumentum/article/view/595. Acesso em: 9 jul. 2019.

FGV - FUNDAÇÃO GETÚLIO VARGAS. Relatório ICG Brasil: 1ํsemestre de 2016. São Paulo, 2016. Disponível em: 
http://bibliotecadigital.fgv.br/dspace/bitstream/handle/10438/17204/RelatorioICJBrasil_1_sem_2016.pdf?sequence=1\&isAllowed=y. Acesso em: 20 ago. 2019.

GALINDO, F.; ROVER, A. J. (coord.). Derecho, gobernanza y tecnologias de la información en la sociedad del conocimiento. In: RUSCHEL, A. J.; ROVER, A. J. Business intelligence: governo eletrônico da justiça. Zaragoza: Prensas Universitarias de Zaragoza, 2009. p. 279-298. Disponível em https://dialnet.unirioja.es/servlet/articulo?codigo=3163929: Acesso em: 20 ago. 2019.

IGLESIAS, P; ARIAS, X. C. El sistema judicial español: una revisión de los principales problemas de la oferta y demanda de tutela judicial. Secretaría General de Presupuestos y Gastos. Instituto de Estudios Fiscales. p. 139-162, 2007.

MADALENO, R. Curso de direito de família. Rio de Janeiro: Forense, 2008.

MALUF, A. C. do R. F. D. Responsabilidade civil por danos ao meio ambiente. In: NERY, R. M. de A., DONNINI, R. Responsabilidade Civil: Estudos em homenagem ao professor Rui Geraldo Camargo Viana. São Paulo: Revista dos Tribunais, 2009.

MARTINS FILHO, I. G. da S. Evolução histórica da estrutura judiciária brasileira. Revista do Tribunal Superior do Trabalho, Brasília, v. 65, n. 1, p. 85-114, out-dez. 1999.

PAGLIARO, A. A vida do sinal: ensaios sobre a língua e outros símbolos. Tradução de Aníbal Pinto de Castro. 2. ed. Lisboa: Fundação Calouste Gulbenkian, 1952.

PINHO, H. D. B. de; CÔRTES, V. A. P. V. As medidas estruturantes e a efetividade das decisões judiciais no ordenamento jurídico brasileiro. Revista Eletrônica de Direito Processual, Rio de Janeiro, v. 13, 2014. p. 229-258.

RAWLS, J. Uma teoria da justiça. Tradução de Almiro Pisetta e Lenita M. R. Esteves. São Paulo: Martins Fontes, 2000.

ROVER, A. J. Sistemas especialistas legais: uma solução inteligente para o Direito. In: ROVER, A. J. (org.). Direito, sociedade e informática: limites e perspectivas da vida digital. Florianópolis: Boiteux, 2000. p. 207-212. Disponível em: http://www.egov.ufsc.br/portal/conteudo/sistemas-especialistas-legais-umasolu\%C3\%A7\%C3\%A3o-inteligente-para-o-direito. Acesso em: 20 ago. 2019.

ROTTA, M.; SARDETO, P. E. da R.; VIEIRA, P.; ROVER, A. J.; SEWALD JUNIOR, E. Alterações resultantes do processo judicial eletrônico. In: ROVER, A. J. (org.). Engenharia e gestão do judiciário brasileiro: Estudos sobre E-justiça. Erechim: Deviant, 2016. p. 411-426. Disponível em: https://www.editoradeviant.com.br/wpcontent/uploads/woocommerce_uploads/2017/03/Engenharia-e-gestao-do-judiciariobrasileiro-Estudos-sobre-E-Justica.pdf. Acesso em: 20 ago. 2019. 
SADEK, M. T. Judiciário: mudanças e reformas. Estudos Avançados, São Paulo, v. 18, n. 51, p. 79-101, maio/ago. 2004.

SEWALD JUNIOR, E. Modelagem de sistema de conhecimento para apoio a decisão sentencial na Justiça Estadual. 2012. 159 p. Dissertação (Mestrado em Engenharia e Gestão do Conhecimento) - Curso de Pós-Graduação em Engenharia e Gestão do Conhecimento. Universidade Federal de Santa Catarina, Florianópolis, 2012. 